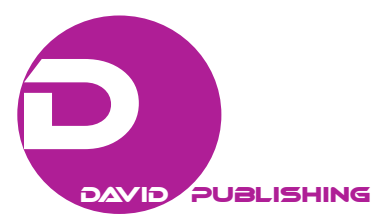

\title{
Wavelets as Basis Functions in the Adaptation's Methods: Author's Model for Forecasting Short-Term
}

\author{
Monika Hadas-Dyduch \\ University of Economics in Katowice, Katowice, Poland
}

\begin{abstract}
The aim of this article is to present author's application of wavelets to predict short-term macroeconomic indicators. Proposed to predict short-term time series (in particular for predicting macroeconomic indicators), proprietary model is based on wavelet analysis with Haar wavelets, Daubechies wavelets, and adaptive models; they are the trend crawling model and alignment exponential model. Adaptive models have been modified through the introduction of wavelet function and combined into a single forecast model. Obtained from conducted research results, it shows the model an effective instrument to predict the short-term.
\end{abstract}

Keywords: wavelets, wavelet transform, multi-resolution analysis, prediction, macroeconomic indicators

\section{Introduction and Literature Review}

Prediction can be performed using various methods and models. They may be mechanical methods based on series analysis, trend models, econometric models cause-and-effect relationships, analog methods, methods based on artificial neural networks, wavelets, etc. (Dyduch, 2010a; 2010b; 2011; Hadas, 2005; 2007; 2009; Hadas-Dyduch, 2013a; 2013b; 2013c; 2013d; 2014a; 2014b; 2014c; 2015a; 2015b).

It is worth mentioning that generally, the multi-resolution analysis is implemented based on Mallaf's algorithm (1999), which corresponds to the computation of the discrete wavelet transform. Several approaches have been proposed for time-series prediction by the wavelet transform, based on a neural network in works of Bashir and El-Hawary (2000), Zheng, Starck, Campbell, and Murtagh (1999), and Lotri'c (2004). According to Zheng et al. (1999) and Soltani, Boichu, Simard, and Canu (2000), the undecimated Haar transform was used.

In the article, in order to predict the time series, it was combined into one model: wavelet analysis with adaptive methods. Combined wavelet transforms with the model of exponential alignment and method of creeping trend. However, the key role of copyright in the proposed model is to perform wavelets. These methods of prediction have been merged into one, creating an appropriate forecasting model—a model wavelet.

In this article, the study used only Daubechies wavelets and Haar wavelets. The Daubechies wavelets are a family of orthogonal wavelets and characterized by a maximal number of vanishing moments for some given support. With each wavelet type of this class, there is a scaling function which generates an orthogonal multiresolution analysis. Furthermore, each Daubechies wavelet is compactly supported. The Daubechies wavelets are neither symmetric nor anti-symmetric around any axis, except for db1, which is in fact the Haar

Monika Hadas-Dyduch, D.Eng., Faculty of Economics, Department of Mathematical and Statistical Methods in Economics, University of Economics in Katowice, Katowice, Poland.

Correspondence concerning this article should be addressed to Monika Hadas-Dyduch, ul. 1 Maja 50, 40-287 Katowice, Poland. 
wavelet. Satisfying symmetry conditions cannot go together with all other properties of the Daubechies wavelets (Daubechies, 1992).

\section{Research Methods}

The purpose for time series prediction model is based on wavelet analysis (with Daubechies wavelets) and adaptive models that are the exponential compensation model and model of creeping trend. Author's model consists of several basic steps. The proposed algorithm for time series prediction using wavelet Daubechies is the original algorithm, named in later working as a model MHD-2. Author's model is designed to predict a single time series. It is intended for short-term prediction.

At the entrance to the model, the author introduced time series $Y$, one-dimensional, and $n$-elements:

$$
y_{1}, y_{2}, y_{3}, \ldots, y_{n-1}, y_{n}
$$

Therefore, first the author determined arbitalnie value of the smoothing constant 1 , which meets two basic conditions, that are:

$$
l \in N \text { and } 2<1<n
$$

The length of the smoothing constant decides about the length of the sub-series, designated from the series $Y$.

The number of sub-series (segment models), that can be formed from a series $Y$, for a chosen length of $l$ is $^{1}$ :

$$
k=n-l+1
$$

where $k$ is the number of segment models and $l$ is smoothing constant.

If the time series consists of $n$ observations on forecasted variable, then on the input estimation procedure of the parameters $k$ of segmented models, the numeric data are got, listed in columns 2 and 3 in the following statements in Table 1.

Table 1

Construction of Sub-series

\begin{tabular}{lll}
\hline$i$ & The values of the time variable $t$ & The empirical values of $i$-th sub-series \\
\hline 1 & $1,2, \ldots, l$ & $y_{1}, y_{2}, \ldots, y_{l}$ \\
2 & $2,3, \ldots, l+1$ & $y_{2}, y_{3}, \ldots, y_{l+1}$ \\
3 & $3,4, \ldots, l+2$ & $y_{3}, y_{4}, \ldots, y_{l+2}$ \\
4 & $4,5, \ldots, l+3$ & $y_{4}, y_{5}, \ldots, y_{l+3}$ \\
$\ldots$ & $\ldots$ & $\ldots$ \\
$k-1$ & $n-l, n-l+1, \ldots, n-1$ & $y_{n-l}, y_{n-l+1}, \ldots, y_{n-1}$ \\
$k$ & $n-l+1, n-l+2, \ldots, n$ & $y_{n-l+1}, y_{n-l+2}, \ldots, y_{n}$ \\
\hline
\end{tabular}

Having sub-series, the author determined for each sub-series, the appropriate extension, and then determined function approximating-wavelet. Approximating function is as follows:

$$
\tilde{f}(r)=\sum_{k=0}^{2^{n}-1} a_{k}^{n-1} \varphi(r / 2-k)+\sum_{k=0}^{2^{n}-1} c_{k}^{n-1} \varphi[(r / 2-1)-k]
$$

Scaling function associated with Daubechies wavelets is described in the following theorems.

Theorem 1. There is exactly one function $\varphi: D \rightarrow R$ which meets the following three conditions:

\footnotetext{
${ }^{1}$ If $n=15, l=5$, then $k=11$. Then you can create 11 segments (sub-series) five-element from mother series 15 -elements.
} 


$$
\begin{gathered}
\varphi(r)=\frac{1+\sqrt{3}}{4} \varphi(2 r)+\frac{3+\sqrt{3}}{4} \varphi(2 r-1)+\frac{3-\sqrt{3}}{4} \varphi(2 r-2)+\frac{1-\sqrt{3}}{4} \varphi(2 r-3) \\
\sum_{k \in \mathbb{Z}} \varphi(k)=1 \\
\varphi(r)=0 \quad d l a \quad r \leq 0 \vee r \geq 3
\end{gathered}
$$

wherein

$$
\begin{gathered}
D_{j}:=k 2^{j}: k \in \mathbb{Z} \\
D:=\bigcup_{j \in \mathbb{Z}} D_{j}=\bigcup_{j=0}^{\infty} D_{j}
\end{gathered}
$$

Associated with scaling function $\varphi$ wavelet $\psi$ setpoint is the formula:

$$
\psi(r)=-\frac{1+\sqrt{3}}{4} \varphi(2 r-1)+\frac{3+\sqrt{3}}{4} \varphi(2 r)-\frac{3-\sqrt{3}}{4} \varphi(2 r+1)+\frac{1-\sqrt{3}}{4} \varphi(2 r+2)
$$

In the next stage, the theoretical values of $Y$ are calculated. In the classical approach to the method of creeping trend for a linear function, $k$ and $l$-elemental "segment" theoretical values forecasted variable were obtained. The way of the calculation is then as follows $\left(k_{i}\right.$ is the number of segment models and $K$ is a set number of segmental model), assuming that $l=3$ in Table 2.

Table 2

Construction of Segments

\begin{tabular}{llll}
\hline$t$ & $k_{i}$ & $K$ & Series of smoothed $\left(\hat{y}_{t}\right)$ \\
\hline 1 & 1 & 1 & $\hat{y}_{1}(1)$ \\
2 & 2 & 1,2 & $1 / 2\left[\hat{y}_{1}(1)+\hat{y}_{2}(2)\right]$ \\
3 & 3 & $1,2,3$ & $1 / 3\left[\hat{y}_{1}(3)+\hat{y}_{2}(3)+\hat{y}_{3}(3)\right]$ \\
$\ldots$ & 3 & $\cdots$ & $\ldots$ \\
$n-2$ & 3 & $k-1, k-2, k$ & $\ldots$ \\
$n-1$ & 2 & $k-1, k$ & $1 / 2\left[\hat{y}_{k-1}(n-1)+\hat{y}_{k-2}(n-1)\right]$ \\
$n$ & 1 & $k$ & $\hat{y}_{k}(n)$ \\
\hline
\end{tabular}

In the proposed model MHD-2 with Daubechies wavelets, approach is not the same as in the classical method of creeping trend. There is a modification. The author determined for each sub-series approximating function and following determined its value at the point $r=0,1,2,3, \ldots, m+1$, where $m$ is the number of elements in the sub-series which determined approximating function.

Having smoothed series by trend creeping-wavelet model ${ }^{2}$, this paper applies the model to alignment exponential — wavelet. Having series of smoothed, creeping trend model—wavelet, this paper applies the model alignment exponential-wavelet ${ }^{3}$. In the classic form of the exponential alignment model, the ratings trend is determined by the following relationship:

\footnotetext{
${ }^{2}$ The trend creeping - wavelet model is an author's concept.

${ }^{3}$ The alignment exponential - wavelet model is an author's concept.
} 


$$
m_{t}=\alpha y_{t}+(1-\alpha) m_{t-1}
$$

wherein,

$$
\begin{gathered}
m_{1}=\hat{y}_{1} \\
t=1,2,3,4, \ldots, n \\
\alpha \in\langle 0,1\rangle
\end{gathered}
$$

Then the forecast for the period $T$, into the future over $h$ individuals, was determined from the following equation:

$$
y_{T}^{P}=m_{n}+h\left(m_{n}-m_{n-1}\right), \quad T \geq 3
$$

In the copyright approach to the exponential—wavelet model, worth $m_{t}$ is determined from the following relationship:

$$
m_{t}=\alpha \hat{y}_{t}+(1-\alpha) y_{t-1}
$$

wherein,

$$
\begin{gathered}
t=2,3,4, \ldots, n, n+1 \\
\alpha \in\langle 0,1\rangle
\end{gathered}
$$

Values are obtained at the output of the trend creeping - wavelets model.

$$
\hat{y}_{1}, \hat{y}_{2}, \hat{y}_{3}, \hat{y}_{4}, \ldots, \hat{y}_{n}, \hat{y}_{n-1}
$$

The copyright approach, the forecast for the next period, that is, for the period $t+1$, is determined from the following relation:

$$
y_{t+1}^{P}=\alpha \hat{y}_{t+1}+(1-\alpha) y_{t}
$$

while for $\alpha$, this paper assumes such a value that gives the minimum error forecasts expired.

\section{Research Results}

In this section of article, an implementation of the model MHD-2 is shown. The aim of implementation is the prediction of macroeconomic indicators of the euro area. A detailed description of the implementation of the MHD-2 is shown for the number of unemployed euro zone countries.

\section{Data}

Data of the numbers of unemployed in the euro area, used to implement of the MHD-2 model, were taken from the Eurostat database. ${ }^{4}$ (...) An unemployed person is defined by Eurostat, according to the guidelines of

\footnotetext{
${ }^{4}$ (...) The time series on unemployment are used by the European Commission, other public institutions, and the media as an economic indicator; banks may use the data for business cycle analysis (...).

(...) In addition to the unemployment measures covered here, Eurostat also publishes statistics for persons who fulfil only partially the definition of unemployment. These persons are not included in the official ILO unemployment concept and have a varying degree of attachment to the labour market. The indicators on underemployment and potential additional labour force participants to supplement the unemployment rate to provide a more complete picture of the labour market (...).
} 
the International Labour Organization ${ }^{5}$, as someone aged 15 to 74 without work during the reference week who is available to start work within the next two weeks and who has actively sought employment at some time

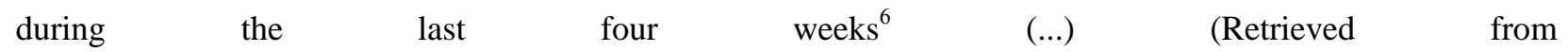
http://ec.europa.eu/eurostat/statistics-explained/index.php/Unemploymentstatistics).

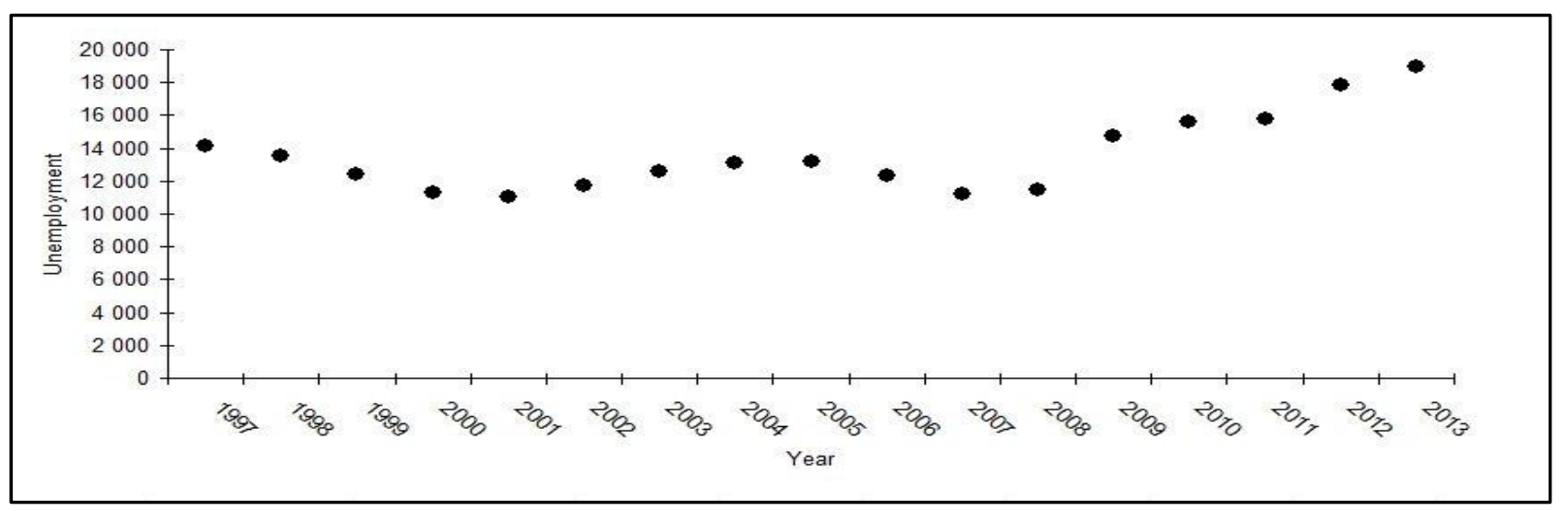

Figure 1. Series Y. euro area (annual average, 1,000 persons). Source: Own elaboration.

As mentioned above in Figure 1, the implementation of the MHD-2 was carried out for a time series, presenting the euro zone ${ }^{7}$ unemployment rate (series $Y$ ) (Retrieved from http://ec.europa. eu/eurostat/statistics-explained/index.php/Unemploymentstatistics). A series included in the research presents the period 1997-2014 year (EA11-2000, EA12-2006, EA13-2007, EA15-2008, EA16-2010, EA17-2013, EA18-2014, and EA19) ${ }^{8}$ - the annual average (1,000 people) (Retrieved from http://ec.europa.

\footnotetext{
${ }^{5}$ The International Labour Organization (ILO) is the United Nations agency for the world of work. It sets international labour standards, promotes rights at work and encourages decent employment opportunities, the enhancement of social protection, and the strengthening of dialogue on work-related issues. The ILO has a unique structure, bringing together governments', employers', and workers' representatives.

The ILO has 185 member States and is the oldest UN agency.

The ILO's Secretariat has its headquarters in Geneva, Switzerland, and a global network of technical experts and field offices in more than 40 countries.

The Governing Body is the executive council of the ILO and meets three times a year in Geneva.

The unique tripartite structure of the ILO gives an equal voice to workers, employers, and governments to ensure that the views of the social partners are closely reflected in labour standards and in shaping policies and programmes.

The ILO was founded in 1919, in the wake of a destructive war, to pursue a vision based on the premise that universal, lasting peace can be established only if it is based on social justice. The ILO became the first specialized agency of the UN in 1946 (...).

${ }^{6}$ Member states may publish other rates, such as register-based unemployment rates or rates based on the national LFS or corresponding surveys. These rates may vary from those published by Eurostat due to a different definition or methodological choices.

${ }^{7}$ (...) The euro area consists of those member states of the European Union that have adopted the euro as their currency. Today, around 340 million citizens in 19 countries live in the euro area and this number will increase as future enlargements of the euro area continue to spread the benefits of the single currency more widely in the European Union (...).

${ }^{8}$ (...) When the euro was first introduced in 1999, as "book" money, the euro area was made up of 11 of the then 15 EU member states. Greece joined in 2001, just one year before the cash changeover, followed by Slovenia in 2007, Cyprus and Malta in 2008, Slovakia in 2009, Estonia in 2011, Latvia in 2014, and Lithuania in 2015. Today, the euro area numbers 19 EU member states.

Of the member states outside the euro area, Denmark and the United Kingdom have "opt-outs" from joining laid down in Protocols annexed to the Treaty, although they can join in the future if they so wish. Sweden has not yet qualified to be part of the euro area.

The remaining non-euro area member states are among those which acceded to the Union in 2004, 2007, and 2013, after the euro was launched. At the time of their accession, they did not meet the necessary conditions for entry to the euro area, but have committed to joining as and when they meet them - they are member states with a "derogation", such as Sweden.

Andorra, Monaco, San Marino, and the Vatican City have adopted the euro as their national currency by virtue of specific monetary agreements with the EU and may issue their own euro coins within certain limits. However, as they are not EU member states, they are not part of the euro area.
} 
eu/eurostat/statistics-explained/index.php/Unemploymentstatistics). However, the model was implemented for the data from 1997 to 2013. Year 2014 was left as a test year. Basic statistics of unemployment are presented in Table 3.

Table 3

A Series of Basic Statistics of Unemployment (Research Period: 1997-2014)

\begin{tabular}{lrrr}
\hline Statistics & \multicolumn{1}{c}{ Value } & Statistics & \multicolumn{1}{l}{ Value } \\
\hline Average & $13,575.76$ & Standard error & 564.73 \\
Median & $13,084.00$ & Scope & $7,924.00$ \\
The standard deviation & $2,328.44$ & Variance sample & $5,421,616.94$ \\
Kurtosis & 0.46 & Skewness & 1.06 \\
Minimum & $11,004.00$ & Maximum & $18,928.00$ \\
\hline
\end{tabular}

Source: Own elaboration.

\section{Sub-series Time}

Assumed smoothing constant $l=4$. Thus, the series $Y$, showing unemployment, was divided into sub-series and four-element. It receives 14 of the following sub-series:

- Sub-series 1: $y_{1}, y_{2}, y_{3}, y_{4}$

- Sub-series 2: $y_{2}, y_{3}, y_{4}, y_{5}$;

- Sub-series 3: $y_{3}, y_{4}, y_{5}, y_{6}$;

- ...

- Sub-series 13: $y_{13}, y_{14}, y_{15}, y_{16}$

- Sub-series 14: $y_{14}, y_{15}, y_{16}, y_{17}$.

\section{Extension}

Obtained sub-series can extend a different method. This article adopted two methods that give the worst performance in wavelet transform.

Expansion's arrays of sub-series of series $Y$ have the following forms:

(1) for the method 1 :

$$
R_{M 1}=\left(\begin{array}{llllllllllll}
0 & 0 & 0 & 0 & y_{1} & y_{2} & y_{3} & y_{4} & 0 & 0 & 0 & 0 \\
0 & 0 & 0 & 0 & y_{2} & y_{3} & y_{4} & y_{5} & 0 & 0 & 0 & 0 \\
0 & 0 & 0 & 0 & y_{3} & y_{4} & y_{5} & y_{6} & 0 & 0 & 0 & 0 \\
0 & 0 & 0 & 0 & y_{4} & y_{5} & y_{6} & y_{7} & 0 & 0 & 0 & 0 \\
0 & 0 & 0 & 0 & y_{5} & y_{6} & y_{7} & y_{8} & 0 & 0 & 0 & 0 \\
0 & 0 & 0 & 0 & y_{6} & y_{7} & y_{8} & y_{9} & 0 & 0 & 0 & 0 \\
0 & 0 & 0 & 0 & y_{7} & y_{8} & y_{9} & y_{10} & 0 & 0 & 0 & 0 \\
0 & 0 & 0 & 0 & y_{8} & y_{9} & y_{10} & y_{11} & 0 & 0 & 0 & 0 \\
0 & 0 & 0 & 0 & y_{9} & y_{10} & y_{11} & y_{12} & 0 & 0 & 0 & 0 \\
0 & 0 & 0 & 0 & y_{10} & y_{11} & y_{12} & y_{13} & 0 & 0 & 0 & 0 \\
0 & 0 & 0 & 0 & y_{11} & y_{12} & y_{13} & y_{14} & 0 & 0 & 0 & 0 \\
0 & 0 & 0 & 0 & y_{12} & y_{13} & y_{14} & y_{15} & 0 & 0 & 0 & 0 \\
0 & 0 & 0 & 0 & y_{13} & y_{14} & y_{15} & y_{16} & 0 & 0 & 0 & 0 \\
0 & 0 & 0 & 0 & y_{14} & y_{15} & y_{16} & y_{17} & 0 & 0 & 0 & 0
\end{array}\right)
$$




$$
R_{M 1}=\left(\begin{array}{llllllllllll}
0 & 0 & 0 & 0 & 14122 & 13503 & 12428 & 11262 & 0 & 0 & 0 & 0 \\
0 & 0 & 0 & 0 & 13503 & 12428 & 11262 & 11004 & 0 & 0 & 0 & 0 \\
0 & 0 & 0 & 0 & 12428 & 11262 & 11004 & 11706 & 0 & 0 & 0 & 0 \\
0 & 0 & 0 & 0 & 11262 & 11004 & 11706 & 12604 & 0 & 0 & 0 & 0 \\
0 & 0 & 0 & 0 & 11004 & 11706 & 12604 & 13084 & 0 & 0 & 0 & 0 \\
0 & 0 & 0 & 0 & 11706 & 12604 & 13084 & 13179 & 0 & 0 & 0 & 0 \\
0 & 0 & 0 & 0 & 12604 & 13084 & 13179 & 12336 & 0 & 0 & 0 & 0 \\
0 & 0 & 0 & 0 & 13084 & 13179 & 12336 & 11238 & 0 & 0 & 0 & 0 \\
0 & 0 & 0 & 0 & 13179 & 12336 & 11238 & 11482 & 0 & 0 & 0 & 0 \\
0 & 0 & 0 & 0 & 12336 & 11238 & 11482 & 14736 & 0 & 0 & 0 & 0 \\
0 & 0 & 0 & 0 & 11238 & 11482 & 14736 & 15565 & 0 & 0 & 0 & 0 \\
0 & 0 & 0 & 0 & 11482 & 14736 & 15565 & 15776 & 0 & 0 & 0 & 0 \\
0 & 0 & 0 & 0 & 14736 & 15565 & 15776 & 17835 & 0 & 0 & 0 & 0 \\
0 & 0 & 0 & 0 & 15565 & 15776 & 17835 & 18928 & 0 & 0 & 0 & 0
\end{array}\right)
$$

(2) for the method 2:

$$
\begin{aligned}
& R_{M 2}=\left(\begin{array}{llllllllllll}
y_{4} & y_{3} & y_{2} & y_{1} & y_{1} & y_{2} & y_{3} & y_{4} & y_{4} & y_{3} & y_{2} & y_{1} \\
y_{5} & y_{4} & y_{3} & y_{2} & y_{2} & y_{3} & y_{4} & y_{5} & y_{5} & y_{4} & y_{3} & y_{2} \\
y_{6} & y_{5} & y_{4} & y_{3} & y_{3} & y_{4} & y_{5} & y_{6} & y_{6} & y_{5} & y_{4} & y_{3} \\
y_{7} & y_{6} & y_{5} & y_{4} & y_{4} & y_{5} & y_{6} & y_{7} & y_{7} & y_{6} & y_{5} & y_{4} \\
y_{8} & y_{7} & y_{6} & y_{5} & y_{5} & y_{6} & y_{7} & y_{8} & y_{8} & y_{7} & y_{6} & y_{5} \\
y_{9} & y_{8} & y_{7} & y_{6} & y_{6} & y_{7} & y_{8} & y_{9} & y_{9} & y_{8} & y_{7} & y_{6} \\
y_{10} & y_{9} & y_{8} & y_{7} & y_{7} & y_{8} & y_{9} & y_{10} & y_{10} & y_{9} & y_{8} & y_{7} \\
y_{11} & y_{10} & y_{9} & y_{8} & y_{8} & y_{9} & y_{10} & y_{11} & y_{11} & y_{10} & y_{9} & y_{8} \\
y_{12} & y_{11} & y_{10} & y_{9} & y_{9} & y_{10} & y_{11} & y_{12} & y_{12} & y_{11} & y_{10} & y_{9} \\
y_{13} & y_{12} & y_{11} & y_{10} & y_{10} & y_{11} & y_{12} & y_{13} & y_{13} & y_{12} & y_{11} & y_{10} \\
y_{14} & y_{13} & y_{12} & y_{11} & y_{11} & y_{12} & y_{13} & y_{14} & y_{14} & y_{13} & y_{12} & y_{11} \\
y_{15} & y_{14} & y_{13} & y_{12} & y_{12} & y_{13} & y_{14} & y_{15} & y_{15} & y_{14} & y_{13} & y_{12} \\
y_{16} & y_{15} & y_{14} & y_{13} & y_{13} & y_{14} & y_{15} & y_{16} & y_{16} & y_{15} & y_{14} & y_{13} \\
y_{17} & y_{16} & y_{15} & y_{14} & y_{14} & y_{15} & y_{16} & y_{17} & y_{17} & y_{16} & y_{15} & y_{14}
\end{array}\right) \\
& R_{M 2}=\left(\begin{array}{lllllllll}
11262 & 12428 & 13503 & 14122 & \ldots & 11262 & 12428 & 13503 & 14122 \\
11004 & 11262 & 12428 & 13503 & \ldots & 11004 & 11262 & 12428 & 13503 \\
11706 & 11004 & 11262 & 12428 & \ldots & 11706 & 11004 & 11262 & 12428 \\
12604 & 11706 & 11004 & 11262 & \ldots & 12604 & 11706 & 11004 & 11262 \\
13084 & 12604 & 11706 & 11004 & \ldots & 13084 & 12604 & 11706 & 11004 \\
13179 & 13084 & 12604 & 11706 & \ldots & 13179 & 13084 & 12604 & 11706 \\
12336 & 13179 & 13084 & 12604 & \ldots & 12336 & 13179 & 13084 & 12604 \\
11238 & 12336 & 13179 & 13084 & \ldots & 11238 & 12336 & 13179 & 13084 \\
11482 & 11238 & 12336 & 13179 & \ldots & 11482 & 11238 & 12336 & 13179 \\
14736 & 11482 & 11238 & 12336 & \ldots & 14736 & 11482 & 11238 & 12336 \\
15565 & 14736 & 11482 & 11238 & \ldots & 15565 & 14736 & 11482 & 11238 \\
15776 & 15565 & 14736 & 11482 & \ldots & 15776 & 15565 & 14736 & 11482 \\
17835 & 15776 & 15565 & 14736 & \ldots & 17835 & 15776 & 15565 & 14736 \\
18928 & 17835 & 15776 & 15565 & \ldots & 18928 & 17835 & 15776 & 15565
\end{array}\right)
\end{aligned}
$$




\section{The Coefficients $\boldsymbol{a}_{k}^{9}$}

By proceeding, according to the wavelet transform algorithm, the coefficients $a_{k}$ for each sub-series with the following formula was determined:

\section{Wavelet Coefficients ${ }^{10}$}

$$
a_{k}=\sum_{r=k+0}^{k+3} \varphi(r-k) s_{r}
$$

By proceeding, according to the algorithm of wavelet transform for the wavelet Daubechies, for the each sub-series wavelet coefficient (for the first level of resolution), the following coefficients are determined:

$$
a_{0}^{n-1}, c_{0}^{n-1}, a_{1}^{n-1}, c_{1}^{n-1}, a_{2}^{n-1}, c_{2}^{n-1}, a_{3}^{n-1}, c_{3}^{n-1}
$$

\section{Segmental Models ${ }^{11}$}

Segmental models determined are based on the formula (1). For the first resolution level, 14 of segmental models are received. For each model, the values for $r=0,1,2,3,4$ are determined. In the classical model of creeping trend, this paper determines for $L=4$ four theoretical values. In the proposed copyright trend crawling wavelet model (application model MHD-2) shall determine the five theoretical-wavelet values ${ }^{12}$ (the first value is always equal to zero).

Obtained values should be saved in the table, just like that it provides the classic method of creeping trend. The fragments of proper arrangement of obtained values are presented in Table 4.

Table 4

Presentation Arrangement the Theoretical Wavelet-Method 1. One Level of Resolution

\begin{tabular}{lrrl}
\hline$f_{1}$ & \multicolumn{1}{l}{$f_{2}$} & \multicolumn{1}{l}{$f_{3}$} & $\ldots$ \\
\hline 0.00 & & & \\
$11,861.24$ & 0.00 & & \\
$18,080.96$ & $180,085.49$ & 0.00 & \\
$13,308.95$ & $274,882.12$ & $182,225.42$ & $\ldots$ \\
$-5,806.08$ & $208,842.12$ & $278,121.42$ & $\ldots$ \\
& $-92,750.89$ & $210,823.08$ & $\ldots$ \\
& & $-93,513.31$ & $\ldots$ \\
\hline
\end{tabular}

Source: Own elaboration.

By calculating the arithmetic average of each row in Table 4, the so-called value theoretical wavelet was received.

In the analyzed example, for one level of resolution wavelet, 19 theoretical-wavelet values were received, namly $t+1$. The obtained values are necessary for the next stage of the model; it is alignment of exponential-wavelet model.

\section{Model Alignment Exponential-Wavelet ${ }^{13}$}

The determined values of theoretical-wavelets: $\hat{y}_{1}, \hat{y}_{2}, \hat{y}_{3}, \ldots, \hat{y}_{t}, \hat{y}_{t+1}$ are necessary to determine the values: $m_{2}, m_{3}, m_{4}, \ldots, m_{t}$ from the equation (7).

\footnotetext{
${ }^{9}$ All results relate to analysis for one level of resolution.

${ }^{10}$ All results relate to analysis for one level of resolution.

${ }^{11}$ All results relate to analysis for one level of resolution.

${ }^{12}$ Invented name, given by the author.

${ }^{13}$ All results relate to analysis for one level of resolution.
} 
Of course, the obtained values significantly deviate from real values ( $\alpha$ was chosen randomly). Therefore, in the next step, error forecasts extinct was determined, for example RMSPE (assumed that, the rest of the model are: $u_{t}=y_{t}-m_{t}$, for $\left.t=2,3,4, \ldots, 17\right)$. Error forecasts extinct minimized changing the value of the parameter $\alpha$.

\section{Analysis and Discussion}

On the basis of the formula (8) and estimated value of $\alpha$, the forecast of the number of unemployed euro zone countries for a further period is determined, it is for the period 18th. Thus,

$$
\begin{gathered}
y_{18}^{P}=\alpha \hat{y}_{18}+(1-\alpha) y_{17} \\
y_{18}^{P}=0.0037 \hat{y}_{18}+(1-0.0037) y_{17}
\end{gathered}
$$

Forecasted number of unemployed euro zone countries in 2014, according to the calculation model MHD-2 is:

- 18,494.3 (in 100 persons) - for the extension of the sub-series Method 1;

- 18,566.7 (in 100 persons) - for the extension of the sub-series Method 2.

The values obtained do not cover one hundred percent of the actual value (Table 5). Among proposed in the MHD-2 model, two methods extension of sample, during the wavelet transform, have more accurate prediction results, giving method 1 .

Table 5

Optimal Prediction Errors the Number of Unemployed People in the Euro Zone Countries, Depending on the Method of Extension Sub-series

\begin{tabular}{lrrr}
\hline Extending of series & \multicolumn{3}{c}{ Error } \\
\cline { 2 - 4 } in wavelet transform & $\mathrm{AE}$ & $\mathrm{PE}$ & $\mathrm{APE}$ \\
\hline Method 1 & 46.3393 & $-0.2512 \%$ & $0.2512 \%$ \\
Method 2 & $1,118.6669$ & $-0.6433 \%$ & 0.0037 \\
\hline
\end{tabular}

Source: Own elaboration.

\section{Conclusions}

It can not conclude that the lower the value of $\alpha$, the more accurate the forecast is, because, as shown by the data presented in Table 6, such bias does not occur. In the model, it is assumed that the optimal solution is a solution for the $\alpha$ which minimizes the error forecasts expired.

Table 6

Errors Prediction

\begin{tabular}{lrrrr}
\hline$\alpha$ & \multicolumn{2}{c}{ AE } & \multicolumn{2}{c}{ PE } \\
\cline { 2 - 5 } & Method 1 & Method 2 & Method 1 & Method 2 \\
\hline 0.0050 & 106.0794 & 7.0146 & $0.5750 \%$ & $0.0380 \%$ \\
0.0045 & 47.4714 & 41.6868 & $-0.2573 \%$ & $-0.2260 \%$ \\
0.0040 & 11.1365 & 90.3883 & $-0.0604 \%$ & $-0.4900 \%$ \\
0.0035 & 69.7444 & 139.0897 & $-0.3781 \%$ & $-0.7540 \%$ \\
0.0030 & 128.3524 & 187.7912 & $-0.6958 \%$ & $-1.0179 \%$ \\
0.0025 & 186.9603 & 236.4927 & $-1.0134 \%$ & $-1.2819 \%$ \\
0.0020 & 245.5682 & 285.1941 & $-1.3311 \%$ & $-1.8099 \%$ \\
\hline
\end{tabular}

Source: Own elaboration. 


\section{References}

Bashir, Z., \& El-Hawary, M. E. (2000). Short term load forecasting by using wavelet neural networks. Proceedings from Canadian Conference on Electrical and Computer Engineering (pp. 163-166).

Daubechies, I. (1992). Ten lectures on wavelets. Philadelphia, PA: SIAM.

Dyduch, M. (2010a). Prognozowanie kursu wymiany euro algorytmem z falka Daubechies. Prace Naukowe: Uniwersytet Ekonomiczny w Katowicach.

Dyduch, M. (2010b). Wspótczynniki transformaty falkowej jako narzedzie generujace prognoze przedziałowa szeregów czasowych. Prace Naukowe: Akademia Ekonomiczna w Katowicach.

Dyduch, M. (2011). Prognozowanie szeregów czasowych w oparciu o wspótczynniki transformaty falkowej, optymalizowane przez sztuczna siec neuronowa. Prace Naukowe: Uniwersytet Ekonomiczny w Katowicach.

Eurostat Database. Eurostat categories: Labour market, statistical article, unemployment [Data file]. Retrieved from http://ec.europa.eu/eurostat/statistics-explained/index.php/Unemploymentstatistics

Hadas, M. (2005). Falki w kontekscie zastosowan ekonomicznych. Prace Naukowe: Akademia Ekonomiczna w Katowicach.

Hadas, M. (2007). Siec falkowo-neuronowa $w$ srodowisku ekonomicznym. Prace Naukowe: Akademia Ekonomiczna w Katowicach.

Hadas, M. (2009). Efektywnosc sieci neuronowej w analizie portfelowej na przykładzie spótek GPW w Warszawie. Prace Naukowe: Akademia Ekonomiczna w Katowicach.

Hadas-Dyduch, M. (2013a). Metoda wspomagajaca wycene składowych inwestycji alternatywnych. Prace Naukowe: Uniwersytet Ekonomiczny w Katowicach.

Hadas-Dyduch, M. (2013b). Prognozowanie szeregów czasowych w oparciu o wspótczynniki transformaty falkowej, optymalizowane przez sztuczna siec neuronowa (Metody matematyczne, ekonometryczne i komputerowe w finansach i ubezpieczeniach 2009, pp. 59-69).

Hadas-Dyduch, M. (2013c). Prognozowanie wskazników makroekonomicznych z uwzglednieniem transformaty falkowej na przykładzie wskaznika inflacji. Zeszyty Naukowe Wyzszej Szkoły Bankowej we Wrocławiu, 2, 175-186.

Hadas-Dyduch, M. (2013d). Efektywnosc inwestycji kapitałowych mierzona modelem opartym na analizie falkowej $w$ niestabilnym otoczeniu gospodarczym (Studia Ekonomiczne No. 174, Uniwersytet Ekonomiczny w Katowicach, pp. 307-313).

Hadas-Dyduch, M. (2014a). Wpływ rozszerzenia próbki przy generowaniu współczynników falkowych szeregu na trafnosc prognozy. Ekonometria, 4(46), 62-71.

Hadas-Dyduch, M. (2014b). Wykorzystanie transformaty falkowej w analizie i predykcji wskazników makroekonomicznych (Studia Ekonomiczne No. 187, Uniwersytet Ekonomiczny w Katowicach, pp. 124-135).

Hadas-Dyduch, M. (2014c). Non-classical algorithm for time series prediction of the range of economic phenomena with regard to the interaction of financial market indicators. Chinese Business Review, 13(4), 221-231.

Hadas-Dyduch, M. (2015a). Wavelets in prediction. Theory, method, simulation. Retrieved from https://www.scholars-press.com/catalog/details//store/gb/book/978-3-639-76844-2/wavelets-in-prediction

Hadas-Dyduch, M. (2015b). Prognozy instrumentów finansowych generowane wspótczynnikami falkowymi z rozszerzeniem (Studia Ekonomiczne No. 227, Uniwersytet Ekonomiczny w Katowicach, pp. 5-15).

Lotri'c, U. (2004). Wavelet based denoising integrated into multilayered perceptron. Neurocomputing, 62, 179-196.

Soltani, S., Boichu, D., Simard, P., \& Canu, S. (2000). The longterm memory prediction by multiscale decomposition. Signal Processing, 80, 2195-2205.

Zheng, G., Starck, J. L., Campbell, J., \& Murtagh, F. (1999). The wavelet transform for filtering financial data streams. Journal of Computational Intelligence in Finance, 7(3), 18-35. 